\title{
Addressing violence against women in the Eastern Mediterranean Region
}

\author{
Maha El-Adawy, ${ }^{1}$ Anna Rita Ronzoni ${ }^{2}$ and Hala Sakr ${ }^{3}$
}

${ }^{1}$ Director, Department of Healthier Population, World Health Organization Regional Office for the Eastern Mediterranean, Cairo, Egypt. ${ }^{2}$ Technical Officer, Gender-Based Violence, World Health Organization Regional Office for the Eastern Mediterranean, Cairo, Egypt. ${ }^{3}$ Regional Advisor, Violence, Injuries and Disabilities, World Health Organization Regional Office for the Eastern Mediterranean, Cairo, Egypt (Correspondence to: Sakrha@who.int)

Citation: El-Adawy M; Ronzoni AR; Sakr H. Addressing violence against women in the Eastern Mediterranean Region. East Mediterr Health J. 2021;27(5):431-432. https://doi.org/10.26719/2021.27.5.431

Copyright (C) World Health Organization (WHO) 2021. Open Access. Some rights reserved. This work is available under the CC BY-NC-SA 3.0 IGO license (https://creativecommons.org/licenses/by-nc-sa/3.o/igo).

New estimates from the World Health Organization (WHO) indicate that about 1 in 3 women globally will face gender-based violence in their lifetime. The WHO Eastern Mediterranean Region has the third-highest prevalence of violence against women worldwide, with $31 \%$ of everpartnered women experiencing physical and/or sexual intimate partner violence at some point in their lives (1). Specific groups of women and girls, such as migrants and undocumented workers, women with disabilities, and women affected by armed conflict or in emergency settings are more vulnerable and may experience multiple forms of violence (2). Health emergencies, as demonstrated during the current COVID-19 pandemic, may also increase the risk of violence against women (3).

Violence is a risk factor for poor health in women, with profound effects on their sexual, reproductive, and mental health and wellbeing $(4,5)$. The documented short- and long-term health impacts of violence reveal how significant a public health problem it is, leading to a broad array of adverse outcomes and resulting in overall social and economic costs for countries (2).

In response, WHO and Member States committed to scaling up the prevention of and response to violence against women through Resolution WHA67.15 (6) and the consequent Global Plan of Action (7). In the framework of the 13th General Programme of Work 2019-2023 (GPW13) and the Regional Vision 2023 (8), WHO set a clear target to reduce such violence. These commitments resonate with related targets of Sustainable Development Goals 5 and 16 .

In the Eastern Mediterranean Region, many efforts have been undertaken to translate these global mandates into actions so that health systems can fulfill their expected role to prevent and respond to violence against women, within a broader multisectoral approach. In this regard, WHO has been providing technical guidance to countries for developing appropriate policies and tools to deliver timely, quality and compassionate health care for survivors of violence. This focused approach led to scaling up of WHO's technical support and direct work on violence against women in 11 countries in the Region.

Since 2019, over 5000 health-care providers in Afghanistan, Iraq, Libya, Pakistan, Palestine, Somalia, Sudan and the Syrian Arab Republic have completed interagency trainings on clinical management of rape and intimate partner violence (CMR/IPV) (9), mental health and psychosocial support for survivors. In addition, approximately 700 health facilities in Afghanistan and Pakistan have been equipped to provide safe care to survivors. Furthermore, to improve data collection WHO supported quality assessments of health facilities in Iraq, Morocco and Sudan. The main gaps identified by these assessments included the lack of trained staff and CMR equipment, as well as data collection and referral pathways. At the policy level, WHO supported the development, update and endorsement of national health policies and guidelines in Afghanistan, Egypt, Iraq and Pakistan. Participatory awareness raising campaigns and initiatives are also conducted in countries in emergency, particularly in the Syrian Arab Republic, and hard toreach areas in collaboration with local stakeholders and communities. Key messages highlight violence against women prevention, health services for women survivors of violence and linkages with other services.

The COVID-19 pandemic and the consequent measures to control the spread of the virus has also brought about an increase in domestic violence $(3,10)$. Available information from women's organizations and hotlines indicate an increase in cases by $50-60 \%$ in the Region during the first lockdown, compared to 2019 data (11). This implies that despite existing challenges, survivors continued to resort to health services as the most accessible and sometimes the only available services. To document health service availability and utilization by gender-based violence survivors in the context of COVID-19, WHO and Health Clusters conducted rapid assessments in Afghanistan, Iraq and Somalia. The findings indicated an increase in health service utilization by survivors, particularly women enduring intimate partner violence, by nearly $40 \%(12)$.

Much work has been done and many achievements were accomplished in the Region. However, much more is still required. There is a clear need to increase key stakeholders' awareness about the importance to integrate violence against women within health systems in a sustainable manner, through developing appropriate policies and guidelines; to continue strengthening healthcare providers capacity; and to generate evidence and knowledge to support undertaken actions.

The role of health in addressing violence against 
women, within a broader multisectoral response, is crucial. The health system is a socially and culturally accepted and trusted entry point. Health-care providers are, at many times, the first point of professional contact for survivors. It is therefore imperative to scale up ongoing efforts and strengthen investment in combating such violence as a health system priority, both in development and emergency contexts in the Region and globally.

\section{References}

1. World Health Organization. Violence against women prevalence estimates 2018. Geneva: World Health Organization; 2020 (https://www.who.int/publications/i/item/violence-against-women-prevalence-estimates, accessed 4 April 2021).

2. UN Women. Forms of violence against women. New York: UN Women; 2020 (https://www.endvawnow.org/en/articles/296-forms-of-violence-against-women-.html, accessed 4 April 2021).

3. Viero A, Barbara G, Montisci M, Kustermann K, Cattaneo C. Violence against women in the Covid-19 pandemic: a review of the literature and a call for shared strategies to tackle health and social emergencies. Forensic Sci Int. 2021;319(110650) (https://doi. org/10.1016/j.forsciint.2020.110650, accessed 4 April 2021).

4. Garcia-Moreno C, Amin A. Violence against women: where are we 25 years after ICPD and where do we need to go? Sex Reprod Health Matters. 2019;27(1):346-348 (https://doi.org/10.1080/26410397.2019.1676533, accessed 4 April 2021).

5. Ali T; Karmaliani R; Farhan R; Hussain S; Jawad F. Intimate partner violence against women: a comprehensive depiction of Pakistani literature. East Mediterr Health J. 2021;27(2):183-194. https://doi.org/10.26719/emhj.20.107

6. World Health Assembly (67.15). Strengthening the role of the health system in addressing violence, in particular against women and girls, and against children. Geneva: World Health Organization; 2014 (https://apps.who.int/iris/handle/10665/162855, accessed 4 April 2021).

7. World Health Organization. Global plan of action to strengthen the role of the health system within a national multisectoral response to address interpersonal violence, in particular against women and girls, and against children. Geneva: World Health Organization; 2016 (https://www.who.int/reproductivehealth/publications/violence/global-plan-of-action/en/, accessed 4 April 2021).

8. World Health Organization. Thirteenth General Programme of Work 2019-2023. Geneva: World Health Organization; 2020 (https://www.who.int/about/what-we-do/thirteenth-general-programme-of-work-2019-2023, accessed 4 April 2021).

9. World Health Organization. Clinical management of rape and intimate partner violence survivors. Developing protocols for use in humanitarian settings. Geneva: World Health Organization; 2020 (https://www.who.int/reproductivehealth/publications/ rape-survivors-humanitarian-settings/en/, accessed 18 May 2021).

10. UN Women. Violence against women and girls and COVID-19 in the Arab Region. New York: UN Women; 2020 (https://arabstates.unwomen.org/en/digital-library/publications/2020/12/violence-against-women-and-girls-and-covid-19-in-the-arab-region, accessed 4 April 2021).

11. World Health Organization Regional Office for the Eastern Mediterranean (WHO/EMRO). COVID-19 and violence against women in the Eastern Mediterranean Region. Cairo: WHO/EMRO; 2020 (https://applications.emro.who.int/docs/EMHLP12oE. pdf?ua=1, accessed 4 April 2021).

12. World Health Organization Regional Office for the Eastern Mediterranean (WHO/EMRO). Rapid assessment of health services response to GBV survivors during COVID-19 emergency in Afghanistan, Iraq, and Somalia. Cairo: WHO/EMRO; 2020 [Unpublished data]. 